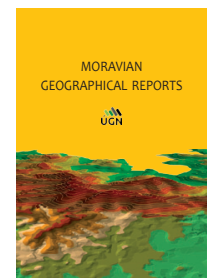

The Czech Academy of Sciences, Institute of Geonics

journal homepage: http://www.geonika.cz/mgr.html

doi: https://doi.org/10.2478/mgr-2020-0006

\title{
When cultural strength means political weakness: Romania's marriage referendum and the paradox of conservative mobilisation
}

\author{
Alexandru RACU ${ }^{a}$, Aurelian GIUGĂL ${ }^{b}$, Ron JOHNSTON ${ }^{c \dagger}$, Alexandru GAVRIȘ ${ }^{\text {* }}$
}

\begin{abstract}
Held on 6-7 October 2018, the Romanian referendum on the topic of gay marriage was the fourth referendum of this kind organised in East Central Europe over a five-year period. Because turnout was low in all of them and demands explanation, this paper: i) discusses the common characteristics of these Eastern European marriage referendums, contextualising the Romanian referendum; ii) overviews the history of the Romanian referendum, emphasising the legal, political, ideological and societal aspects; iii) quantitatively examines the electoral geography of the voting patterns; and iv) interprets qualitative data seeking to understand the voters' choices and why conservative mobilisation was so weak.
\end{abstract}

Keywords: referendum, same-sex marriage, electoral geography, East Central Europe, Romania

Article history: Received 24 January 2020, Accepted 30 May 2020, Published 30 June 2020

\section{Introduction}

In the last thirty years, the global advance of LGBT rights in the form of legalisation by states of same-sex unions and same-sex marriage (SSM) is evident. By the end of 2018, SSM had been legalised in 25 countries (in some cases only within certain sub-national jurisdictions), while same-sex unions had been legalised in 17 others. This trend highlights an impressive wave of policy convergence, 'a new social phenomenon' (Chamie and Mirkin, 2011), inspired by sociopolitical change and EU policies (Kollman, 2007, 2017).

In several countries, the issue of SSM has been decided through a referendum. In Ireland, a large majority of members of a non-partisan Constitutional Convention voted in favour of legalising SSM, advising the Prime Minister to hold a referendum on the issue (Elkink, Farrell, Reidy and Suiter, 2017). Elsewhere, when Parliaments have attempted to legalise gay marriage, opponents have successfully requested that it be decided by a referendum (as in Taiwan and Slovenia) or, as in the Romanian case, opponents of SSM have successfully requested the organisation of a referendum with the specific purpose of preventing future possible legalisation of SSM, preceding any possible attempt to do so within normal Parliamentary procedures.

Romania's Marriage Referendum, held on 6-7 October, 2018, was not an isolated event, therefore. Similar referendums have been organised in Croatia (2013), Ireland (2015), Slovakia (2015), Australia (2017), Taiwan (2018), and twice in Slovenia (2012 and 2015). Moreover, between 1998 and 2015 (the year in which gay marriage became legal throughout the United States as a result of a Supreme Court decision in Obergefell v. Hodges, 2015), referendums on SSM involved 35 states, in four of them twice (Cahill and Cahill, 2004; Simon, Matland, Wendell and Tatalovich, 2018). Of the 39 total referendums, 34 were won by opponents of gay marriage. Supporters of gay marriage were successful in Australia and Ireland, while opponents prevailed in Slovenia, Croatia and Taiwan (for more information about Taiwan's referendum: see Hung, 2018).

\footnotetext{
${ }^{a}$ Independent Researcher, Bucharest, Romania

${ }^{\mathrm{b}}$ Faculty of Journalism and Communication Studies; Interdisciplinary Center of Advanced Research on Territorial Dynamics, University of Bucharest, Romania

${ }^{c}$ School of Geographical Sciences, University of Bristol, UK († Ron Johnston died suddenly during the final editorial processing of this article, on May 29, 2020. See also the Postscripts by the authors and Editor-in-Chief, Bryn Greer-Wootten at the end of this article)

${ }^{\mathrm{d}}$ Faculty of Business and Tourism, The Bucharest University of Economic Studies, Romania (*corresponding author: A. Gavriș, e-mail: alexandru.gavris@rei.ase.ro)
} 
In Australia, there was no formal referendum, as the government organised instead a postal survey (McAllister and Snagovsky, 2018; Wilson, Shalley and Perales, 2019). Gay marriage was subsequently legalised by Parliamentary decision: the government had previously said that there would be no vote on the issue in Parliament should the majority of respondents in the survey be opposed to gay marriage, but would allow a free vote for MPs if there was a majority in favour. Turnout was 79.5 per cent with 61.6 per cent in favour: only four MPs did not vote for the subsequent Act implementing the plebiscite decision, after the Senate had voted 43 - 12 in favour (Gravelle and Carson, 2018; McAllister and Snagovsky, 2018). In Slovakia and Romania, although a large percentage of those who voted were against gay marriage, the referendums were invalidated due to the lack of a quorum, as turnout was less than a specified minimum.

In such a context, our paper poses an empirical question: Why did so few Romanians turn out to vote in the referendum? This question is particularly pertinent given the apparent innate conservatism in the country. For example, Romania comes second and fourth in a poll in which people were asked if (i) they believe in God, and (ii) how important religion is in their lives (Pew Research Center, 2017). This specific question is explored through analyses of the geography of voting using a mixed-method approach. In a broader perspective, analyses related to SSM have been undertaken, especially in the United States context (Chapman, 2011; Chapman, Leib and Webster, 2011; Brown, Kopp and Morrill, 2005; Webster, Chapman and Leib, 2010). These works have emphasised a paradigmatic framework focused on contemporary cultural politics and cultural conflicts (Sharp, 1996; Brown, Kopp and Morrill, 2005). As Wolfe (1999) has argued, debates over the proper place of gays in society have remained a central divide in American political culture. In post-socialist circumstances, however, such conflicts are relatively new, embedded in local contexts and politics. Informed by such particularities and within the under-explored terrain of attitudes to SSM in Eastern Europe, this paper seeks a theoretically-based answer that scrutinises particular regional issues and particular conditions - to illustrate how conservative cultural strength is translated into conservative political weakness.

\section{The regional specificity of East Central European referendums}

Excluding the United States, with its multiple statelevel referendums, out of seven countries that organised referendums on SSM in recent years, five are European and four of which are Eastern European, suggesting that it is a region where the gay rights agenda encounters significant political resistance. Whereas most Western European countries have legalised SSM, no East Central European country has so done, and many of those countries, including Romania, do not offer any sort of legal cohabitation formula for same-sex couples.

Unlike the referendum in Ireland, all East Central European referendums on SSM have been organised as a result of pressures from below, exercised by ConservativeChristian organisations with similar ideologies and tactics. In each country, gay rights were perceived and presented by these organisations as a threat to (traditional) family values.

In all four East Central European cases, LGBT and Human Rights groups opposed referendums. In Romania and Slovakia, anticipating that it would be impossible to obtain a majority of votes favouring SSM and recognising the legal provision that establishes a validation quorum of 30 per cent in Romania and 50 per cent in Slovakia, these same groups and their political allies opted for the strategy of boycotting the referendum (so that the quorum threshold would not be reached) - which proved successful. Such a strategy was excluded in Croatia, where there is no validation quorum, and in Slovenia, where a referendum result is validated if the majority of ballots cast for either YES or NO represents 20 per cent of registered voters (Forest, 2018; Krasovec, 2015; Kroslak, 2015; Rybar and Šovč́ková, 2016; Slootmaeckers and Sircar, 2018).

Although polls have indicated that, compared to Western Europeans, Eastern Europeans are significantly more conservative when it comes to SSM, for example with a minimum of eight per cent of Dutch and a maximum of 83 per cent of Bulgarians opposed (European Commission, 2015), this social profile is translated only partially, and in the Slovak and Romanian case insufficiently, into clear electoral outcomes favouring traditional marriage. Whereas polling data show that 63 per cent of Croatians, 46 per cent of Slovenians, 76 per cent of Slovaks, and 79 per cent of Romanians oppose SSM (European Commission, 2015), turnout in their referendums on this issue has been relatively low: 37.9 per cent in Croatia, 36.4 per cent in Slovenia, 21.4 per cent at Slovakia's second referendum, and 21.1 per cent in Romania.

These percentage differences apparently place Croatia and Slovenia, on the one hand, and Romania and Slovakia, on the other hand, in two distinct categories: the first of which is characterised by low voter turnout (around 37 per cent) and the second by very low voter turnout (around 20 per cent), reflecting the notion that the quorum threshold led to the referendum being boycotted by the progressive camp in Romania and Slovakia, but not in Croatia and Slovenia. This difference of strategy is clearly reflected in the voting results: whereas in Croatia and Slovenia 63.5 and 65.9 per cent of voters respectively who turned out voted against SSM, 91.6 per cent did so in Romania and 94.5 per cent in Slovakia's second referendum in 2015 (throughout this paper, we refer only to this second Slovakian referendum). If, however, the votes against SSM are expressed as a share of the electorate (i.e. including those who abstained), there are only small differences between the four countries: 25, 23, 20 and 19 per cent respectively for Croatian, Slovenian, Slovak and Romanian electors. This means that 59.5 per cent of all Croatian voters, 50 per cent of Slovenians, 73.5 per cent of Slovaks and 75.5 per cent of Romanians opposed to SSM apparently did not vote against it in the referendums, clearly demonstrating the weakness of conservative mobilisation against SSM these countries there.

The LGBT referendums in the East Central European countries indicated a variety of strategies contextualised by the local electoral and social conditions. From these perspectives we elaborate next the case of the Romanian marriage referendum.

\section{The Romanian marriage referendum: Legal aspects, politics, society and the ideological divide}

Romania's SSM referendum was initiated and promoted by Coaliția pentru Familie (CPF: The Pro-Family Coalition), a federation of conservative and Christian NGOs which united Orthodox, Catholics and Protestants. Margarit (2019) has detailed the evolution of LGBT rights in post- 
socialist Romania and of the conflict between pro-LGBT and conservative groups. The initiative benefitted from the support of the Romanian Orthodox Church and all officially recognised religious groups in Romania (Damian, 2018). Christian parishes belonging to all denominations were instrumental in gathering the signatures necessary to initiate the process of constitutional revision. CPF's aim was to amend Article 48, Paragraph 1, of the Romanian Constitution, by replacing the existing wording - "The family is established through the freely agreed marriage between spouses" - with a new one meant to eliminate any ambiguity concerning the strictly heterosexual nature of the family: "The family is established through the freely agreed marriage between a man and a woman".

For this purpose, an Initiative Committee was constituted in October 2015 and started the legal proceedings needed to amend the Constitution. Under Romanian law, the revision process can be initiated by citizens if they gather at least 500,000 signatures, including at least 20,000 signatures per county in at least half of the country's 42 counties (including Bucharest). Between November 2015 and May 2016, CPF gathered approximately 2,700,000 signatures, which were officially submitted to Parliament on 23 May, 2018. In Romania's post-socialist history, this was the first grassroots initiative aimed at amending the Constitution through a referendum (for how referendums in Romania are not used primarily as a means to reflect citizens' opinions on policy issues: see Gherghina, 2019).

The next step required by Romanian law is validation of the initiative by the Constitutional Court, which has to verify whether the proposed amendment respects the limits within which the Constitution can be amended, limits listed in Article 152. Of particular importance in this case was Paragraph 2 of Article 152, which states that "no revision is allowed if its result is the suppression of fundamental rights and freedoms of the citizens". Opponents of the initiative argued that, regardless of gender and sexual orientation, the right to marry is a fundamental human right which would have been breached if the amendment was passed. Thus, 24 liberal and progressive Romanian NGOs called on the Constitutional Court to reject CPF's initiative, their plea being endorsed by four international NGOs: Amnesty International, The International Commission of Jurists, The International Lesbian, Gay, Bisexual, Trans and Intersex Association, and The European Commission on Sexual Orientation Law. At the same time, two American Conservative Christian organisations - Liberty Counsel and The Alliance Defending Freedom - urged the Court to validate it. On 20 July, 2016, the Court ruled unanimously that the proposed amendment did not contradict the provisions of Article 152, Paragraph 2 (Monitorul Oficial, 2016).

The next step in the process was approval of the amendment by Parliament. Under Romanian law, in order to be finally submitted to the decision of the electorate through a referendum, a constitutional amendment must first be approved by two-thirds of the members of the Chamber of Deputies and two-thirds of the members of the Senate, or, should this not be the case, by threequarters of the members of both chambers sitting in a joint session. Overwhelming majorities of Deputies and Senators passed the proposed amendment on 9 May, 2017 (Chamber of Deputies) and 11 September, 2018 (Senate). The only Parliamentary party that consistently opposed the referendum - despite a few cases of internal dissent - was the centre-right Save Romania Party (USR).
In the referendum campaign, the Social Democratic Party (PSD) and Popular Movement Party (PMP) called on voters to vote YES, while the Alliance of Liberals and Democrats (ALDE), National Liberal Party (PNL) and Democratic Alliance of Hungarians in Romania (UDMR), advised them to vote according to their conscience. USR, on the other hand, urged voters to boycott the referendum, this being the official position of the country's main LGBT organisations, MOZAIQ and ACCEPT, as well as of the overwhelming majority of intellectuals and public figures supportive of the LGBT community, plus extra-parliamentary parties, such as the Romania Together Movement (MRÎ) of former Prime Minister Dacian Cioloș and the leftist Party of Democracy and Solidarity (DEMOS). Thus, the debate was not a divide between those in favour of voting for the amendment and those in favour of voting against it, but rather a divide between those in favour of a YES vote and those who chose to boycott the referendum. Anticipating, on the basis of known public opinion, that it would be impossible to reject the amendment at the ballot box, the overwhelming majority of those opposed to it opted for the "stay at home" strategy, in the hope that the referendum would be invalidated for lack of a quorum, a strategy which proved correct.

As far as public debate was concerned, while some sophisticated points of view were put forward by both conservative and progressive pundits, the ideological division can be reduced to the following positions: supporters of the amendment presented the referendum as a hallmark of democracy and sovereignty, arguing that "children are at stake!" - homosexuals will be able to adopt children and children's minds would be polluted by promiscuous sexual education and "the gender ideology". On the contrary, opponents insisted that it is illegitimate to "vote on rights" or to "vote on love" - hence, their campaign slogan: "thou shall not vote on love!". Opponents also argued that Romania's democracy was threatened by a fundamentalist offensive, which, sooner or later, would also lead to the banning of abortion and divorce. One campaign video even warned that, should the amendment pass, Romania would go back to the Middle Ages and opponents of the new religious ideology burned at the stake.

Further, CPF was accused of shady connections with American fundamentalist Christian organisations and with Putin's Russia: an article argued that "Putin does not need armed threats in order to sever Romania from the European Community, the Nord-Atlantic Treaty and other alliances. He only needs the Pro-Family Coalition" (Danciu, 2016). A few days before the referendum, 43 academics, public intellectuals, activists and artists signed a public appeal against the Referendum, denouncing what they viewed as an anti-European campaign based on hatred, similar to the fascist campaigns of the 1930s and the communist ones from the 1940s and $1950 \mathrm{~s}$. According to the signatories, the politicians who voted for the organisation of the referendum were attacking democracy itself, with the purpose of "instituting a type of authoritarian oligarchy with theocratic elements, similar to the one in Russia" (Anonymous, 2018). In return, NGOs and liberal intellectuals opposed to the amendment were labelled as "Soros instruments", and the LGBT ideology denounced as a form of Western cultural imperialism, used by "globalist elites" and "Western corporations" in order to reduce Romania to the status of a colony.

This sort of discourse is not unrelated to that employed in other contexts by the ruling PSD. Locked in a conflict with European authorities over accusations that they (EU) seek to 
reverse Romania's progress in the fight against corruption, which has also led to mass protests and violent street clashes with law enforcement agencies on the streets of Bucharest, PSD has been accused - and not always without reason - of trying to mobilise conservative and nationalist sentiment as a way to consolidate their power in opposition to the European Union. Supporting arguments (by PSD) related to concerns about the efforts of pro-European elements of Romanian civil society to curb PSD' attempts to undermine the rule of law and reverse Romania' progress in the fight against corruption. The leader of PSD, Liviu Dragnea, was sentenced (with suspension) for illegal electoral campaigning in 2016 and then, in 2018, for abuse of power. The Parliamentary opposition and civil society accused him of trying to reverse Romania's progress in the fight against corruption, and even of trying to take Romania out of the European Union, so that he and fellow party members would escape imprisonment. Thus, a key aspect of the Romanian referendum was an overlap - largely either circumstantial or explained by political opportunism - between the marriage debate and the corruption debate, the latter also having geopolitical implications as far as Romania's relations with the EU and NATO were concerned.

This overlap has been far from uniform. While television networks opposed to the ruling coalition and leaders of the anti-corruption social movement urged voters not to vote in "Dragnea's referendum", Christians opposed to PSD and supportive of the fight against corruption voted nevertheless, criticising the attempt of some to associate PSD and the referendum as illegitimate. Some even accused fellow Christians, who refused to vote due to this association, of betraying the Christian faith for the sake of ephemeral political goals (the prominent examples were Ludovic Orban and Dacian Cioloș, leaders of the opposition parties). Even some USR deputies voted in favour of organising the referendum, and one left the party because of its decision to boycott the referendum.

Finally, in the weeks prior to the referendum, false information or "fake news" (much of it distributed via online platforms such as Facebook), according to which a vote in favour of the amendment would give the ruling coalition the possibility to modify Romania's Constitution as they pleased, circulated in the Romanian public sphere, and some even argued that this was part of a disinformation campaign conducted by opponents of the amendment. Another example of "fake news" that circulated via social media in the weeks prior to the referendum was the theory that, independently of what people voted, the Constitution would be amended only if the ruling coalition so wished. In reality, the referendum was not merely consultative, as with some referendums held in post-socialist Romania, but decisional, a majority of votes in favour of the amendment, if at least 30 per cent of registered voters were present at the ballot box, leading automatically to the modification of the Constitution. To assess the extent to which this issue also had an impact on the final result, our interviews explored how many respondents opposed to SSM did not vote either because they associated (legitimately or not is a different question) the referendum with the corrupt interests of the ruling coalition, or because of sheer disinformation and a failure to understand what was actually at stake.

Taking into account the continuously downward trend of voter turnout throughout Romania's post-socialist period at the most recent Parliamentary and European Parliament elections prior to the referendum it was below 40 per cent
(Comşa, 2015) - the 21.1 per cent turnout in the referendum (a historic low in Romania) was not really surprising. Although the YES vote was overwhelming (91.6 per cent), the 30 per cent validation threshold was not reached. Turnout was higher in rural areas (24.4 per cent), with a maximum of 96.5 per cent (a Dolj county locality), and lower in urban areas (17.5 per cent), with a maximum of 57.9 (in Dâmbovița). Only one county (Suceava) had turnout above 30 per cent. There were also regional turnout differences: it was higher in less-developed regions like Oltenia ( 23.5 per cent) than in the most prosperous -15.8 per cent in Transylvania.

This section has provided an overview of the developments that led to the organisation of the so-called marriage referendum in Romania and the public debate that preceded the referendum. In the next section we turn to an analysis using the quantitative data-sets.

\section{The pattern of voting in Romania's marriage referendum}

Given the above background, substantial variations within the population were anticipated in terms of whether they voted in the referendum and, if so, how. In general, support for the initiative should have been greatest among the more conservative elements of society, whereas decisions to boycott it should have been greatest among the more liberal groups, stimulated by one of the main political parties that many of them supported. Since in many countries, conservative values and attitudes are generally more prevalent in rural than in urban areas, and in those less developed economically, an urban-rural divide in support for the initiative was anticipated - although the degree to which this was reflected in the voting patterns would depend also on whether there were significant spatial variations in turnout.

\subsection{Quantitative analysis}

To evaluate these arguments in the absence of survey data, we use ecological data on the referendum result at the locality level: there are 3,181 such localities in the country. Varying in the number of registered voters between 96 and $1,790,385$ (Bucharest), these areas had a mean of 5,746 (standard deviation: 35,879 ) and a median of 2,488 (interquartile range: $1,677-3,564)$. The localities were classified into three groups: villages, of which there were 2,861 with a mean registered electorate of 2,727 (standard deviation: 1,742); 217 cities with a mean electorate of 8,856 (standard deviation: 7,832); and 103 municipalities with a mean electorate of 83,058 (standard deviation: 35,430 ). Both cities and municipalities are urban localities and are defined by law; they differ by size, plus economic and administrative functions. A city is a territorial and administrative locality where non-agricultural activities prevail and which exerts an influence over the neighbouring area. Municipalities are important urban localities with an economic structure comprising mainly secondary and tertiary activities and a population, generally, of at least 40,000 inhabitants. In Romania, every county has a county capital. In 41 urban municipalities, all the bureaucratic, administrative and the more important industrial activities are located there. Villages were expected to have the more conservative populations and thus, the highest turnout rates: almost onethird of villages had turnout levels exceeding the national average of 21.1 per cent for all localities, compared to just 9 per cent for cities and 2 per cent for municipalities. 
Most of those who voted were, as expected, in favour of the referendum's proposition: the percentage voting yes averaged 90.6 across the 3,181 localities (standard deviation: 4.09), with no significant differences across the three settlement types. Of more interest is the percentage of the total electorate (i.e. including abstainers) who voted yes, which averaged 23.2 (standard deviation: 11.5); on this measure, percentage support was significantly greater in the villages (mean 23.9) than in the other two categories (the mean for cities was 16.0 and for municipalities 18.1). Conservative values were stronger in the smaller settlements.

To further these analyses, regression models were formulated (using IBM SPSS software) with the following independent variables:

- Turnover per person: this is a measure of the volume of economic activity in a locality, which should be negatively related to both the turnout percentage and the percentage of the electorate voting yes - more economically developed areas should have smaller conservative populations; because the variable is highly skewed positively, it is entered in the regressions in its logarithmic form ( $\log$ base 10 ).

- Percentage voting for USR at the 2016 general election: because the USR recommended a boycott of the referendum, this should be negatively related to turnout levels - again, because of a heavy positive skew this variable is logarithmically transformed;

- Percentage voting for PSD at the 2016 general election: because the PSD recommended a 'yes' vote this should be positively related to the percentage who voted yes;

- Locality type: dummy variables for villages and municipalities, with cities as the comparator; more commonly called the baseline;

- Counties: initial exploratory analyses suggested that models including the above variables had both low R2 values and substantial residual values for each of the country's 42 counties, so dummy variables for these were included in the model, with the comparator being Covasna county, which had the lowest levels of both turnout and percentage of the electorate voting yes (Covasna is one of the two counties with a large Hungarian population - the other is Harghita).

The results of these regressions are reported in Table 1. For turnout, as hypothesised this was significantly lower the larger the per capita turnover in a locality, suggesting that higher levels of economic activity were associated with higher abstention rates; similarly, the greater the support for USR at the previous general election, the lower the turnout. In addition, holding those two variables constant, villages on average had higher turnout than cities and municipalities, with no significant difference between the latter two. All of the counties had significantly higher turnout levels than the comparator; the county that differed least from Covasna is Harghita, the other one with a large Hungarian population. Apart from Harghita, three groups of counties stand out: those with turnout levels greater than Covasna, but by no more than 17 points; those with much higher turnout levels than Covasna, 20 points or more; and an intermediate group (see Fig. 1, which shows the average difference in turnout between places in each county and those in Covasna, holding the other variables constant).

The 16 counties with the largest regression coefficients (over 20) have low levels of urbanisation and include the economically relatively underdeveloped counties from
Moldavia (Botoșani, Suceava), Wallachia (Buzău, Giurgiu, Teleorman) and Oltenia (Dolj, Olt, Mehedinți), where the overall percentage obtained by PSD in these localities at the 2016 general election was the country's highest 51.1 per cent. The group also includes Bihor and Suceava counties which contain Romania's largest Baptist and Pentecostal communities: 59,894 in Bihor and 50,852 in Suceava. Some have suggested a possible tie between turnout there and the number of members of these religious minorities (Iosip, 2018). Moreover, CPF's first meeting, where the proposed revision of the Constitution was discussed, took place in Vatra Dornei (Suceava county), and the following two meetings were in Oradea (Bihor county). Suceava is also a stronghold of Orthodox monasticism, with some of the largest and most active Orthodox monasteries in the country.

Among the counties with regression coefficients between 13 and 20 there are both underdeveloped areas such as Bacău, Călărași and Vrancea, but also two of the most developed counties in the country - Timis and Cluj. In the last category, counties with coefficients below 13 , there are two other counties, besides Covasna and Harghita with significant Hungarian minorities (39.3 per cent in Mureș and 34.5 per cent in Satu-Mare) but, somewhat surprisingly, also two counties from Dobrudja, Tulcea and Constanța, which are not as prosperous. PSD obtained its lowest vote share (39.7 per cent) in these six counties in 2016 indeed a correlation between the county coefficients and the vote for PSD is positive $\left(r^{2}=0.25\right)$ but not statistically significant.

Regarding the percentage of the electorate who voted yes, Table 1 shows that this was on average higher in villages than either cities or municipalities, that, as hypothesised, it increased the larger the PSD's share of votes cast in the locality in 2016, and decreased the higher the per capita average turnover - i.e. the more prosperous the locality the lower turnout there. Most of the coefficients for the individual counties were statistically larger than that for the comparator - Covasna - with an increase exceeding 20 points in one case (the percentage voting yes in localities in Harghita county was, holding the other variables constant, on average four points higher than in Covasna). Ten out of the twelve counties with regression coefficients greater than 10 are those with high turnout coefficients - Bihor and Suceava among them. Most of the counties (26) have coefficients between 0-10 (Fig. 2, which shows the difference in turnout between each county and Covasna, holding all other variables constant). This is similar to the YES vote at the county level: in 37 out of 42 counties, the percentages for YES vote are in the 90.1-94.6 interval. Even in the

\begin{tabular}{lcccc}
\hline & \multicolumn{2}{c}{ Turnout } & \multicolumn{2}{c}{ Per Cent Voted Yes } \\
\hline Constant & 11.43 & $(2.24)$ & 9.02 & $(1.95)$ \\
Village & 3.07 & $(0.73)$ & 3.52 & $(0.65)$ \\
Municipality & -1.54 & $(1.19)$ & -1.64 & $(1.07)$ \\
logTurnover & -1.65 & $(0.35)$ & -1.74 & $(0.30)$ \\
logUSR2016 & -4.02 & $(0.62)$ & - & - \\
PSD2016 & - & - & 0.20 & $(0.01)$ \\
County dummies & Yes & & Yes & \\
$\mathrm{R}^{2}$ & 0.35 & & 0.40 & \\
\hline
\end{tabular}

Tab. 1: Regression models of voting at the locality scale Source: authors' computations 


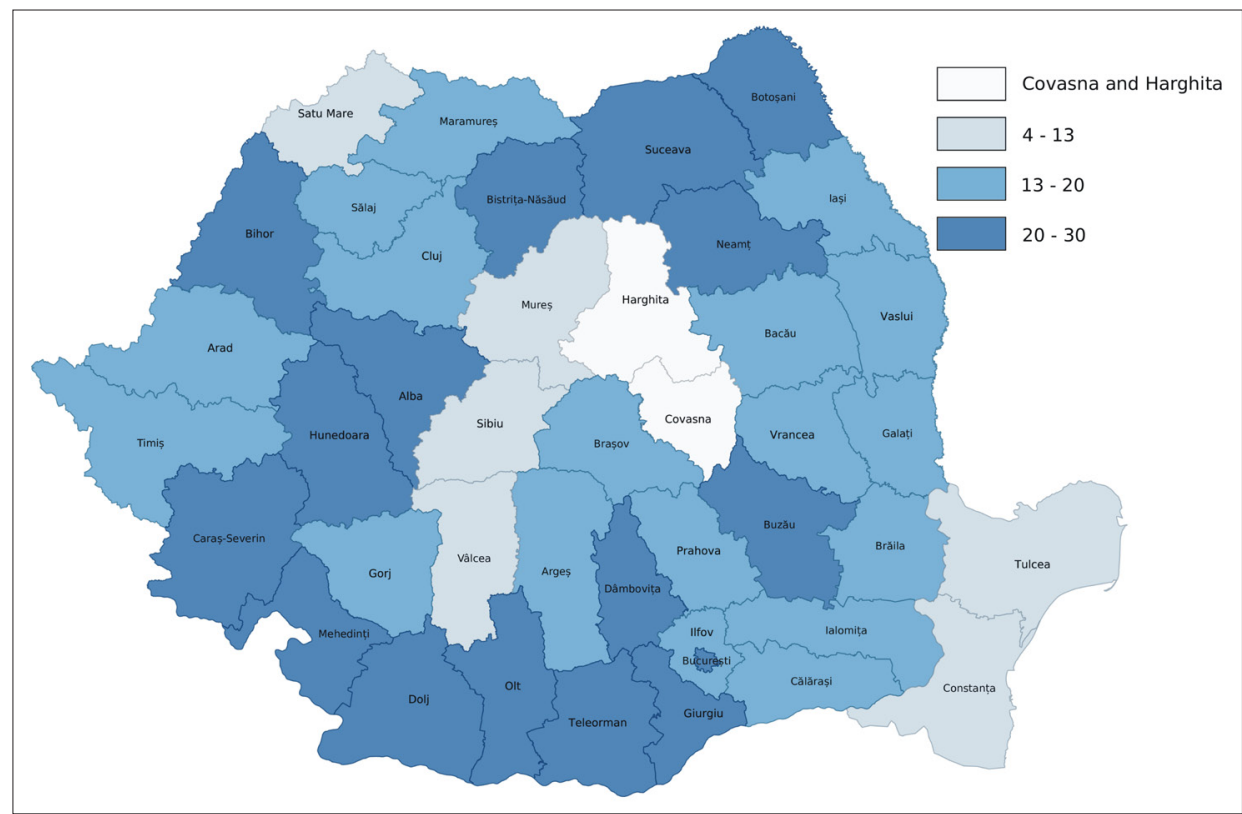

Fig. 1: Map of the coefficients for individual counties from the turnout regression in Table 1 Source: authors' computations

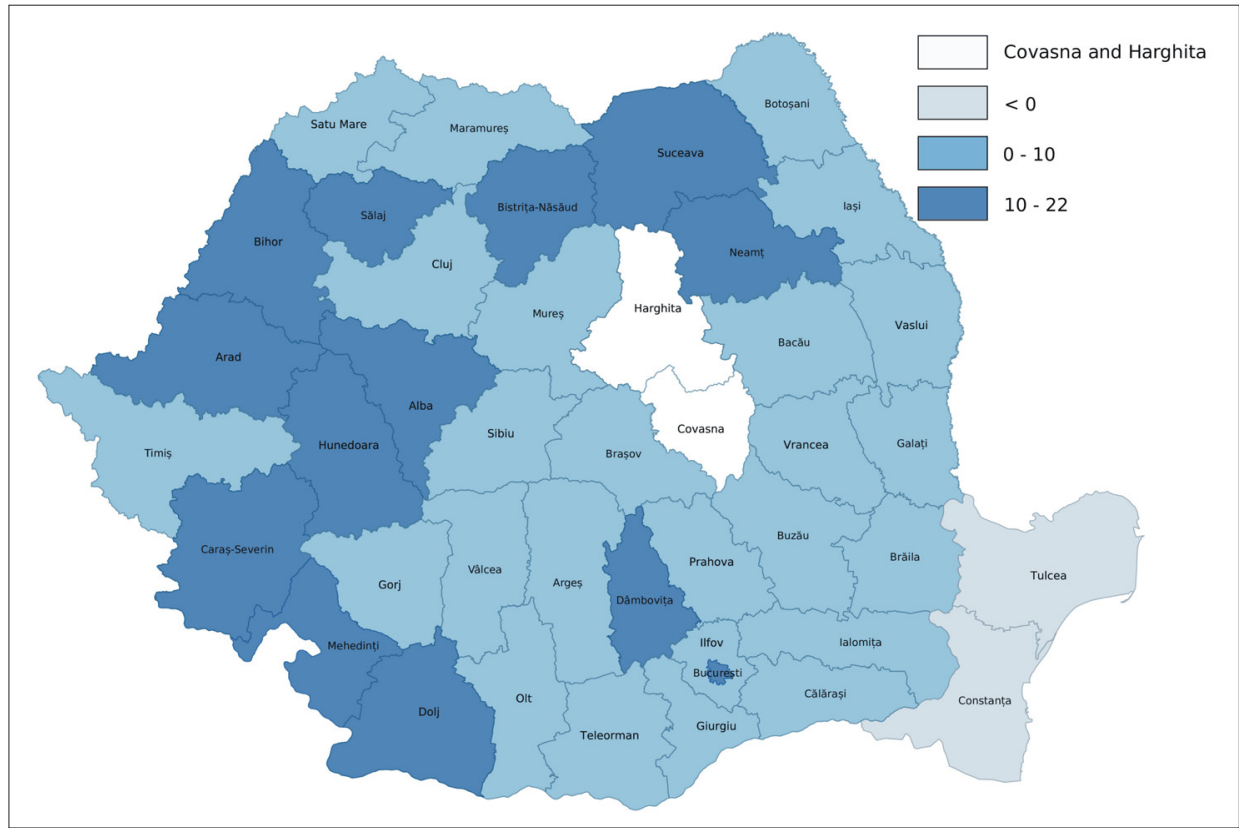

Fig. 2: Map of the coefficients for individual counties from the percent voted yes regression at the county scale Source: authors' computations

counties with negative coefficients, Constanța and Tulcea, YES vote percentages are slightly lower than the national average, 87.4 and 88.3 .

Given the significant differences across counties, a further analysis was undertaken at that scale, for which a wider range of economic variables was available. Five of these were subjected to a principal components analysis: a single component with an eigenvalue of 3.8 accounted for 76 per cent of the variance, with high loadings on all five variables (see Tab. 2).

The scores on this factor were interpreted as a measure of economic development: the higher a positive score, the more urbanised and economically prosperous the county. The intention was to include the percentages who voted USR and PSD in the analyses of turnout and voting yes, respectively, but both - unsurprisingly - were collinear with the factor score (Score), as was the percentage of each county's population living in villages. Thus the only other variable included was a dummy comparing the two counties where

\begin{tabular}{lr}
\hline Per Cent Employed in Agriculture & -0.82 \\
Per Cent Living in Urban Areas & 0.81 \\
GDP per capita & 0.97 \\
Average Salary & 0.87 \\
Average Turnover per capita & 0.89 \\
\hline
\end{tabular}

Tab. 2: Principal components factor analysis of five economic activity variables for Romanian counties Source: authors' computations 
members of the Hungarian minority are concentrated with the other 40 counties. The results were (standard errors in brackets and significant coefficients in bold):

Per Cent Turnout $=21.25(0.60)-\mathbf{2 . 1 4}$ Score $(0.59)-\mathbf{1 1 . 8 9}$ Hungarian (2.76); $\mathrm{R}^{2}=0.46$;

Per Cent of the Electorate Voted Yes $=19.41(0.57)-\mathbf{1 . 9 4}$ Score (0.56) - 10.86 Hungarian (2.60); R2 = 0.39.

These results confirm those obtained at the locality scale. Turnout was lower, the more urbanised and prosperous the county (where the less conservative elements of Romanian society are concentrated and USR had most support), and was especially low in the two Hungarian counties. Support for the proposal to restrict marriage to a union between a man and a woman also declined the more urbanised and prosperous the area, and was again on average even lower in the two Hungarian counties.

Having explored the quantitative pattern of voting in Romania's referendum, the following section frames the qualitative part of the methodology and explores its results. We have followed the suggestions of Brown, Knopp and Morill (2005), who have argued in favour of a mixed-methods approach which, according to them, should offer a better understanding of electoral geography. While existing studies on gay rights referendums have analysed local political contexts, public debates and electoral geographies, apart from doing this in the Romanian context, our study also adds a grassroots qualitative analysis meant to elucidate the weak mobilisation of conservative voters in Romania's marriage referendum.

\subsection{Qualitative research: Design issues}

The aggregate-level analyses have identified clear patterns of voting in line with the general hypotheses regarding both turnout and support for the referendum's proposition linking both turnout levels and support for the proposition to levels of economic development and social conservatism but they provide few insights into why the turnout levels were so low and about voting behaviours. To appreciate further why many people opposed to SSM nevertheless did not vote in the referendum, interviews were held across Romania's five main regions (Transylvania, Wallachia, Oltenia, Dobrudja and Moldavia) attempting to balance the number of interviewees to the country's characteristics: Baker and Edwards (2012) argue that 12-60 participants (in total) are advisable for such a study. After some trial interviews (November, 2019) to calibrate the questions asked and with the help of peer researchers, debriefings about what areas should be explored and what questions should be adjusted, the fieldwork commenced. Some 50 interviews were completed by using a convenience sampling approach, which aimed to interview a wide range of respondent during December, 2018 and March, 2019. The interviews, lasting between 20-40 minutes, were hand-recorded by the first and the second authors of this paper, who then coded the answers, while the second and the fourth author checked the coding processes. All the transcriptions and the initial thematic analysis were in Romanian and were followed by their translation to English. The third author, an Englishspeaking person, ensured that the data could be scrutinised from a variety of perspectives and indicated the exploration of various nuances. The interviewees were over 18 years and willing to express their views on the referendum: the results do not represent a representative sample of the Romanian population, therefore, but the opinions expressed provide supportive information for the aggregate analyses of the voting patterns. Therefore, our attempt is to obtain narratives reflective of the referendum and to provide an understanding of the more general picture of the event, related to conservative non-participation.

The interviews were conducted in ten urban localities and five villages. In terms of populations, three are large municipalities (Braşov, Bucharest and Craiova), two are medium-sized municipalities (Brăila and Pitești), two are medium-small municipalities (Bârlad and Tulcea), and three are small cities (Balș, Dăbuleni and Sinaia). There are important development differences between these places, the cities from Transylvania and Wallachia being the most developed. In rural areas, we interviewed people from five villages (located in Oltenia and Transylvania): a cluster of interviews was obtained in Oltenia to obtain the views of those with conservative views living in localities with low economic development and where PSD gained 60 per cent of the votes at the 2016 general election. One, an isolated village with a large Roma community, is distinguished by its poverty, a large proportion of the active population being on welfare. Among those interviewed were members of ethnic and confessional minorities (Roma, Hungarians); their ages ranged from 20 to 70 years and they included people who had completed primary and secondary school (22\%), people who completed high-school (30\%), university graduates (38\%), plus some holding a post-graduate degree (10\%).

The interviewers were confronted with several problems. Many respondents initially willing to discuss the matter considered it trivial. Others were frightened by the possibility of the interviewers being involved with a certain party. Another group asked why they were not interviewed before the referendum to inform them about it and what it means. Finally, the most complex problem was encountered in Transylvania, where some people asked the interviewers to leave because they did not want to hear about PSD and Dragnea.

\section{Why did they vote or not... and if they did, why did they vote for or against?}

Of the fifty persons interviewed (Tab. 3), 36 did not vote in the referendum: 35 were clearly against SSM; two were indifferent - they simply did not care whether homosexuals are allowed to get married or not; six were clearly in favour of SSM; and seven were in favour of SSM but without the right to adopt. These counts largely correspond to the national voter turnout, and to what polls indicated about the views of Romanians on this issue. Statistically, those in favour of SSM were younger and better educated: 40 per cent were under 35 and two-thirds had a bachelor's or a postgraduate degree. By comparison, those opposed to gay marriage were older and less educated: only 20 per cent were under 35 and only 40 per cent had a postgraduate degree. There were no significant differences between the two groups in religious practice, however: about one-fifth of both those in favour of and those opposed to SSM, attended Church services at least once a month.

While none of those either indifferent to SSM or clearly in favour of it voted in the referendum, six out of eight people in favour of SSM, but without the right to adopt children, did not vote, while the other two from this subgroup voted NO. These were the only two respondents who voted NO, and one was the only respondent out of all 50 who invoked the "fake news" concerning "Dragnea's plan" to change the Constitution in whatever way he wished, as the reason for 


\begin{tabular}{|c|c|c|c|c|c|c|}
\hline & \multirow[b]{2}{*}{ Total } & \multirow[b]{2}{*}{ Vote } & \multirow[b]{2}{*}{ Did not vote } & \multicolumn{3}{|c|}{ The 23 persons who were against SSM but did not vote } \\
\hline & & & & $\begin{array}{l}\text { Against the ruling } \\
\text { coalition }\end{array}$ & $\begin{array}{l}\text { Regarded the } \\
\text { referendum as a } \\
\text { waste of resources }\end{array}$ & $\begin{array}{l}\text { Mixture of } \\
\text { explanations }\end{array}$ \\
\hline Voted/did not vote & 50 & 14 & 36 & - & - & - \\
\hline Against SSM & 35 & 12 & 23 & 6 & 3 & 14 \\
\hline Indifferent & 2 & 1 & 1 & - & - & - \\
\hline In favour of SSM & 6 & 0 & 6 & - & - & - \\
\hline In favour but not adoption & 7 & 1 & 6 & - & - & - \\
\hline
\end{tabular}

Tab. 3: Qualitative study: Interviewees' characteristics

Source: authors' field survey accounts

voting NO. Two other respondents, who, though opposed to SSM, did not vote, invoked another type of "fake news", saying that their vote did not matter anyway, for regardless of the result, politicians would amend the Constitution only if they so wished. Yet one of them said that, despite this belief, she would have voted YES anyway, for this is what her conscience told her to do; but in the end she did not vote because she was out of town and did not take the time to inform herself whether she could vote out of her constituency (which was indeed possible). The other person was confused: not only did she think that politicians would do as they pleased, independently of what people voted, but she also thought that the referendum was actually a trap whose real purpose was to legalise SSM, and voting in the referendum would facilitate this aim.

Overall, the findings suggest that the "fake news" circulating in the Romanian media and social media during the campaign did not have a significant influence on voters. Sheer disinformation seems to have had a more significant impact: when asked if they knew about CPF's initiative and the proposal to amend the constitutional definition of marriage, nine respondents (18 per cent) said they did not.

Only 12 (34 per cent) of the 35 people opposed to SSM voted in the referendum. The other 23 (66 per cent) abstained, which means (in this case) that more than two-thirds of respondents opposed to SSM did not vote. This clearly suggests that conservative mobilisation was very weak. When people spoke about their absenteeism, a couple of motivations stood out. Contrary to what some opposition leaders suggested, dislike of the ruling coalition did not represent the main reason for failure to participate in the vote. Among the respondents opposed to SSM (23), only six identified this as the reason for not voting. Five of them came from Transylvania, a wealthier region, traditionally supportive of the center-right parties. On the other hand, the sixth person from this group, an elderly peasant from South-West Romania spoke less about political corruption, but about the questionable morality of the ruling coalition leaders: Dragnea and Tăriceanu (Dragnea is divorced and involved in a relationship with a much younger woman, while Tăriceanu has been married five times.). In the contemporary Romanian rural world, more traditional moral perceptions are widespread. Consequently, a candidate's personal behaviour matters a great deal in the eyes of the electorate, sometimes more than the candidate's political agenda.

Several respondents (3) argued that the referendum did not make sense, as the public agenda should be about pressing socio-economic issues, not 'bedroom issues'. For these people, who live in a poor settlements, organising such a referendum was a needless waste of resources. These respondents stated that they did not perceive SSM as a threat to their way of life, one of them saying "I felt that by not going to vote, 'these' (gay people) would gain some rights. Even so, the outcome cannot change our lives, our life would remain the same.... In the end, I believe that SSM would be legalised due to the enforcement by the EU." They did not think gay marriage could be legalised in Romania any time soon, since the overwhelming majority of Romanians were firmly against it. They felt that their own culture was strong enough and had no need to be rescued by CPF.

The remaining 14 respondents who, though opposed to SSM, failed to turn out, represent the most interesting category and they were the most difficult to interview. These 14 were unable to offer a clear reason for not voting. What could be observed was a cognitive dissonance between their opposition to SSM and their behaviour on voting day. When asked whether they agreed with SSM they clearly answered that they did not. But when asked why they didn't vote against it, they offered a variety of excuses such as family duties, staying home and relaxing, going to another locality and had doubts about the possibility of voting there, alongside many day-to-day activities (Gherghina et al., in print).

One respondent from this category represented a more interesting case. A more informed and ideologically articulate conservative, he attacked Western 'political correctness' and said that, beyond the fact that he disliked gay parades and believed that a child should have a father and mother, he opposed SSM because he saw it as part of a contemporary trend which, in the name of equal rights, ends up by granting minorities more rights than those enjoyed by the majority. Aware of the fact that very few people from his rural settlement went to vote, he told us that 'all his neighbours were totally against SSM, but did not vote because, though totally opposed to SSM, they are nevertheless interested in more practical issues'. He inferred that if homosexuals would appear in the community, then the whole village would have voted in the referendum.

Indeed, the common characteristic of almost all respondents who, though opposed to SSM, did not vote in the referendum - and had not, on the other hand, justified their course of action through their political opposition to the ruling coalition - was that they did not seem at all affected by the 'fears' (intensively) cultivated in the Romanian media and social media. They were not afraid that Dragnea's Social Democrats were about to use the referendum to advance allegedly corrupt purposes and 
they were certainly not responsive to the fears cultivated by liberals and leftists regarding the perspective of a fundamentalist onslaught that would include, in the near future, the banning of abortion and divorce, in the circumstances in which there was no hint that they would agree with such measures. But neither were they responsive to the fears cultivated by CPF regarding the 'gender ideology' and the 'danger' that homosexuality represents for 'our children'. Many people, especially in rural spaces, suggested that such an issue is typical in more developed European societies, not in their communities. They were unable to regard the issue on which they were supposed to vote, however, as something serious or, in some cases, comprehensible even. They simply inhabited a world which was disconnected from the public sphere in which a very passionate cultural war was being waged.

Many respondents considered that they did not have a reason to be afraid of gay people. Their reasoning was supported by not seeing gay people. While they heard about them, it is mainly a 'Western thing' and because - as they believed there are so many gay people in the Romanian Parliament that this matter developed to such a scale to make politicians organise a referendum. It was another world that mattered to them, a world concerned with everyday life, distanced from a political debate seen as not being 'for them'. Traditionally opposed to gay matters, they thought their collective life would not be affected, and if that would happen then they would solve it. Therefore, the debate about the referendum regarding the definition of family in the Constitution and gay rights found them in their own world, a world where life and politics moves slowly; hence, it was no reason for them to mobilise given the lack of relevance to them.

When trying to understand the low turnout, one should also take into account the weak mobilisation levels that were reported by respondents, much lower than what they were used to during electoral campaigns (Gherghina et al., in press). Respondents said that in their locality or those which they know about, only few people were actively informed by the parties or the Church. Moreover, some appeared to be ignorant about the campaign saying that they did not know about the CPF nor were they informed through any campaigning materials (Gherghina et al., in press). Combined with the unconventional topic of the SSM debate, this further contributed to the confusion of many voters who failed to understand why they were called to vote, when voting seemed so different from what they were used to. For them voting was about the distribution of power and resources and was associated with efforts made by parties to gain their vote. Now it was about an incomprehensible lifestyle with which most of them never came into contact, not even remotely, and was associated with an equally bizarre, perhaps even suspicious, indifference of local political elites with regard to voting.

Last but not least, another aspect of the low turnout related to the priests' involvement. Respondents indicated that priests campaigned little or not at all outside of the church. The situation was even more complicated, as some of those interviewed had negative views not only of politicians but of the clergy as well, whom they regarded as worldly and greedy. One person said that the clerics lacked moral authority and consequently would be met with indifference or disdain.

Highly motivated during the campaign for gathering signatures, conservative mobilisation faded before the referendum. It failed to reach out beyond those who already signed for the organisation of the referendum. The delay in holding the referendum and the Romanian political dynamics created a context where mobilisation was seen as being related to other topics. In this regard, more efforts were exerted by the opponents of the referendum to influence people not to vote. Political parties that officially supported the referendum made little or no effort to actually get people to vote, while the Church approached the same people who usually attended the sermons. The mobilisation efforts remained therefore in a state of suspended animation in a debate that shifted its course. Although it is unknown how such efforts might have worked out - some could claim that they were useless anyway, or even that they could have backfired - it is likely that their absence explains, at least to some extent, the failure of the referendum.

\section{Concluding remarks}

The conclusion of this study, which may or may not be confirmed by a broader nation-wide investigation, is that the explanation for the low turnout that led to the invalidation of the referendum, does not reside in a widespread popular adherence to the tenets of the progressive camp nor to its tactics of boycotting the referendum, even though these tactics, facilitated by the Romanian electoral law, may have proved decisive for its failure. Yet, the threshold would have been reached easily in the circumstances of a fairly active conservative mobilisation. But such mobilisation was catastrophically weak because the efforts of conservative elites - political parties that supported a YES vote, the Church, and CPF itself - to mobilise the mass of voters otherwise opposed to gay marriage, were either scarce and/ or inefficient. The electoral geographical analysis shows that the turnout was higher in rural localities, in poorlydeveloped regions and in localities where Social Democrats are strong. Conversely, in large cities, developed regions, and where the USR performed well at the 2016 Parliamentary elections, turnout was weak.

As for the main reasons invoked by opponents of SSM for not voting, two stand out, the second being significantly more prevalent and therefore weighing more in the final result. The first reason was opposition to the ruling coalition and its leader, Dragnea, motivated especially by the respondents' identification with the anti-corruption campaign that dominates Romanian politics. Hence, it appears that the existence of a "conflict of interests", where support for cultural conservatism overlaps with opposition towards other political actions and the ideas of the politicians who champion cultural conservatism, undermined the mobilisation potential for undertakings such as the one initiated by CPF. The second reason is that many people, though opposed to SSM, were not "mobilised" against it. They either did not understand the stake and meaning of the referendum, or saw it as something that was rather awkward and not serious. Last but not least, though opposed to SSM, they simply were not receptive to the "fear" - cultivated by $\mathrm{CPF}$ and which motivated its demarche in the first place that the LGBT movement was capable of successfully pushing for the legalisation of SSM in Romania and that, more broadly, it represented a "threat" to their way of life, and hence worth mobilising against. This perception and its subsequent political consequence are largely explained by the unchallenged strength of the conservative culture in which they live, hence pointing towards the paradox in which conservative cultural strength is translated into conservative political weakness. 
Finally, given that weak conservative mobilisation in marriage referendums is not limited to Romania, but appears to be relatively general across East Central Europe, it would be interesting to replicate this analysis in other East European countries where marriage referendums were held - to see whether or not similar explanations identified in the Romanian case apply there. Beyond Eastern Europe, a comparison with the Irish referendum, where, despite the clear and resounding victory of progressives, conservative mobilisation was extremely efficient, could confirm this final intuition: where conservatism is culturally strong, it is also dormant; and being dormant, from a political point of view, it is also weak, or, in any case, not strong enough. CPF appears to have failed because of bad timing. In this sense, its attempt to wake up Romania's huge conservative majority happened too early. But one may also legitimately ask whether the paradox of conservative mobilisation described here, is not necessarily reflected in another paradox of conservative awakening: by necessity, when conservatives eventually wake up, it is already too late for them.

\section{Acknowledgements}

We greatly thank to Sergiu Gherghina for his insights that allowed the expansion of our ideas. We also thank to the organisers of Elections, Public Opinion and Parties 2019 Conference. Alexandru Gavriș has attended the 2019 EPOP Conference thanks to a FSS Shanghai mobility grant. A special thanks to Igor Sîrodoev who provided data from a grant of the Romanian National Authority for Scientific Research and Innovation, CNCS - UEFISCDI, project number PN-II-RU-TE-2014-4-1481. Thanks to Buciu Petre and Gheorghiță Zbăganu for their observations.

\section{References:}

BAKER, S. E., EDWARDS, R. (2012): How many qualitative interviews is enough. National Centre for Research Methods Review. Discussion Paper [online]. [cit. 9.12.2018]. Available at: http://eprints.ncrm. ac.uk/2273/4/how_many_interviews.pdf

BROWN, M., KNOPP, L., MORRILL, R. (2005): The culture wars and urban electoral politics: sexuality, race, and class in Tacoma, Washington. Political Geography, 24: 267-291.

CAHILL, S., CAHILL, S. R. (2004): Same-sex marriage in the United States: Focus on the facts. Lanham, Maryland, Lexington Books.

CHAMIE, J., MIRKIN, B. (2011): Same-sex marriage: A new social phenomenon. Population and Development Review, 37(3): 529-551.

CHAPMAN, T., LEIB, J., WEBSTER, G. R. (2007): Race, the creative class, and political geographies of same sex marriage in Georgia. Southeastern Geographer, 47(1): 27-54

CHAPMAN, T. (2011): Sexual politics and the sunshine state: Electoral geographies of Florida's marriage protection amendment. In: Barney, W., Leib, J. [eds.]: Revitalizing Electoral Geography (pp. 219-232). Farnham, Ashgate Publishing Limited.

COMȘA, M. (2015): Turnout Decline in Romanian National Elections: Is It That Big? Studia Universitatis BabesBolyai Sociologia, 6(2): 59-84.

DAMIAN, Ș. (2018, October): Toate cultele religioase din România sprijină referendumul pentru familie [online]. [cit. 10.12.2018]. Available at https://publicnewsfm. ro/2018/10/03/toate-cultele-religioase-din-romaniasprijina-referendumul-pentru-familie/

DANCIU, T. (2016): Cum au ajuns prietenii lui Putin și fondatorul Noua Dreaptă să formeze Coaliția pentru Familie [online]. [cit. 22.11.2018]. Available at: https:// www.vice.com/ro/article/53bkmz/cine-sunt-oamenii-dinspatele-coalitiei-pentru-familie

ELKINK, J. A., FARRELL, D. M., REIDY, T., SUITER, J. (2017): Understanding the 2015 marriage referendum in Ireland: context, campaign, and conservative Ireland. Irish Political Studies, 32(3): 361-381.

EUROPEAN COMMISSION (2015): Discrimination in the EU in 2015. Special Eurobarometer 437 (Report). Brussels, European Commission.

FOREST, M. (2018): Europeanizing vs. Nationalizing the Issue of Same-Sex Marriage in Central Europe: A Comparative Analysis of Framing Processes in Croatia, Hungary, Slovakia, and Slovenia. In: Winter, B., Forest, M., Sénac, R. [eds.]: Global perspectives on samesex marriage: A neo-institutional approach (pp. 127148). Cham, Springer International.

GHERGHINA, S. (2019): Hijacked Direct Democracy: The Instrumental Use of Referendums in Romania. East European Politics and Societies, 33(3): 778-797.

GHERGHINA, S., RACU, A., SILAGADZE, N., GIUGĂL, A., JOHNSTON, R., GAVRIȘ, A. (in print): Non-Voting in the 2018 Romanian Referendum: The Importance of Initiators, Campaigning and Issue Saliency. Political Science.

GRAVELLE, T. B., CARSON, A. (2018): Explaining the Australian marriage equality vote: An aggregate-level analysis. Politics, 39(2): 186-201.

HUNG, W. S. (2018): An Empirical Analysis of Same-Sex Marriage in Taiwan. Theoretical Economics Letters, 8(15): 3301-3312.

IOSIP, F. (2018, October): Cum au ajuns Suceava și Bihor să aibă cea mai mare prezență la referendum [online]. [cit. 8.04.2019]. Available at: https://adevarul.ro/news/ eveniment/cum-ajuns-suceava-bihor-cea-mai-mareprezenta-referendum-1_5bbb8077df52022f754d5d60/ index.html

KOLLMAN, K. (2007): Same-Sex Unions: The Globalization of an Idea. International Studies Quarterly, 51(2): 329-357.

KOLLMAN, K. (2017): Pioneering marriage for same-sex couples in the Netherlands. Journal of European Public Policy, 24(1): 100-118.

KRASOVEC, A. (2015): The Referendum in Slovenia (2015). East European Quarterly, 43: 225-233.

KROSLAK, D. (2015): The Referendum on the so-called Traditional Family in the Slovak Republic. Central and Eastern European Legal Studies, 1: 149-167.

MARGARIT, D. (2019): LGBTQ rights, conservative backlash and the constitutional definition of marriage in Romania. Gender, Place \& Culture, 26(11): 1570-1587.

MCALLISTER, I., SNAGOVSKY, F. (2018): Explaining voting in the 2017 Australian same-sex marriage plebiscite. Australian Journal of Political Science, 53(4): 409-427.

MONITORUL OFICIAL (2016): Decizia nr. 580 din 20 iulie 2016 asupra inițiativei legislative a cetățenilor intitulată „Lege de revizuire a Constituției României”. Monitorul 
Oficial [online]. [cit.18.11.2018]. Available at: https:// www.ccr.ro/files/products/Decizie_580.pdf

Obergefell v. Hodges, No. 14-556 (2015): Supreme Court, US.

PEW RESEARCH CENTER (2017): Eastern and Western Europeans Differ on Importance of Religion, Views of Minorities, and Key Social Issues [online]. [cit. 29.10.2018]. Available at: https://www.pewforum. org/2017/05/10/religious-belief-and-national-belongingin-central-and-eastern-europe/

REVISTA22 (2018): Apelul privind «campania urii» care marchează referendumul, semnat de zeci de intelectuali [online]. [cit. 12.12.2018]. Available at: https://revista22. ro/actualitate-interna/apelul-privind-campania-urii-caremarcheaz-referendumul-semnat-de-zeci-de-intelectuali

RYBAR, M., SOVCIKOVA, A. (2016): The 2015 Referendum in Slovakia (March 2016). East European Quarterly, 44: 79-88.

SHARP, E. B. (1996): Culture wars and city politics. Local government's role in social conflict. Urban Affairs Review, 31(6): 738-758.
SIMON, C.A., MATLAND, R.E., WENDELL, D. G., TATALOVICH, R. (2018): Voting turnout and referendum outcomes on same-sex marriage, 1998-2015. Social Science Quarterly, 99(4): 1522-1534.

SLOOTMAECKERS, K., SIRCAR, I. (2018): Marrying European and Domestic Politics? The Marriage Referendum in Croatia and Value-Based Euroscepticism. Europe-Asia Studies, 70(3): 321-344.

WEBSTER, G. R., CHAPMAN, T., LEIB, J. (2010): Sustaining the "societal and scriptural fence": Cultural, social, and political topographies of same-sex marriage in Alabama. The Professional Geographer, 62(2): 211-229.

WILSON, T., SHALlEY, F., PERALES, F. (2019): The geography of Australia's Marriage Law Postal Survey Outcome. Area, 52(1): 164-175.

WOLFE, A. (1998). One nation, after all: How middle-class Americans really think about: God, country, family, racism, welfare, immigration, homosexuality, work, the right, the left, and each other. New York, Viking Penguin.

\section{Please cite this article as:}

RACU, A., GIUGĂL, A., JOHNSTON, R., GAVRIȘ, A. (2020): When cultural strength means political weakness: Romania's marriage referendum and the paradox of conservative mobilisation. Moravian Geographical Reports, 28(2): 70-80. Doi: https://doi.org/10.2478/ mgr-2020-0006

\section{Postscripts}

Ron Johnston, one of the world's most influential political geographers, is no longer with us. He died suddenly on May 29, aged 79. Ron's death was a huge shock for everyone who knows him. Right up until the end, Ron continued working and analysing, as he had done all his life. Ron never really stopped writing: he wrote and wrote. His knowledge and intellectual energy were absolutely fantastic. An influential scholar, he was also a very unselfish man. Everyone who was in contact with Ron will remember him as an exceptionally kind, formidably loyal and generous friend. I cannot put into words how important he was to me. In such a materialistic world, where many are perfectly selfish and distant, Ron was the total opposite. Simply said, Ron was a very fine man. I have no words to say how lucky I was to know and to work with as a passionate scholar as Ron. But Ron was not just a mentor, but a tender-hearted friend and a brilliant colleague. As Derek Gregory said, indeed, Big Ron, magnificent Ron!

Aurelian Giugăl, on behalf of the co-authors

Ron Johnston was one of my academic friends in the very best sense of a friend - constant, consistent, attentive, critical in all the right ways, always generous to a fault. For the profession at large, it is likely that he will be remembered primarily for his prodigious publication record: more than 1,000 articles in the peer-reviewed literature, more than 40 books and 40 edited collections, about 150 chapters in books, including very useful entries in various encyclopedias, many incisive book reviews and commentaries on 'current trends'. But he was also a 'doer', as well as an accomplished writer, with several important contributions to public life, such as those to the Boundary Commission for England. His original research was primarily in Urban Geography, but over the years he worked relatively exclusively in Political Geography and in the History of the Discipline, all the while maintaining a very strong interest in the analytical (mostly quantitative) possibilities of drawing the 'right' conclusions. For many he will be remembered most of all for his leadership of the different collectives involved in producing the various editions of 'The Dictionary of Human Geography', an invaluable and extensive resource for students of the discipline of all ages, from undergraduates to retired university professors. Importantly, he never stopped learning, willing to admit changes in interpretations, as techniques for evaluating such changes emerged. For example, he eventually changed from the interpretation of contextual effects (e.g. on voting in elections) evaluated by means of econometric spatial regressions, to the more valuable multi-level modelling approaches endorsed in recent publications. Even in this current article in MGR, with his co-authors, he incorporates the values of mixed methods research designs, with greater value placed on qualitative methods than usual. He was always learning. If I may be allowed at least one brief personal story from long ago: it was in 1972 when Ron was a Visiting Associate Professor at the University of Toronto. I met him in his office there, before lunch. He was correcting the galley proofs for 'Urban Residential Patterns', a classic that we used in our senior undergraduate courses thereafter. After a few beers at lunch, I somehow gained enough strength - the temerity - to ask him how he could produce so many publications per year: by then, after only seven years since his first article, he had already more than fifty refereed articles in print! His reply was, as ever, simple yet profound: "Before I go to bed, every night, I must complete at least one paragraph!". Add up the 55 years since his first publication, and you have one of likely many answers. Ron Johnston would have appreciated that, smiling. 